УдК 378.147.091.33 - 027.22:54

\title{
ЮЛІЯ БОХАН
}

\section{ТЕТЯНА ФОРОСТОВСЬКА}

Центральноукраїнський педагогічний університет імені Володимира Винниченка, м. Кропивницький

\section{жолт коРМош}

Східноєвропейський національний університет імені Лесі Українки, м. Луцьк

\section{ЗАПРОВАДЖЕННЯ КОМПЛЕКСНОГО ПІДХОДУ ДО ХІМІЧНОГО ПРАКТИКУМУ ПІД ЧАС ПІДГОТОВКИ МАЙБУТНІХ УЧИТЕЛІВ ПРИРОДОЗНАВЧИХ ДИСЦИПЛІН}

\begin{abstract}
Стаття присвячена підготовці вчителів інтегрованих курсів природознавчих дисциплін 3 використанням сучасних інформаційних технологій навчання під час вивчення дисципліни «Загальна та неорганічна хімія». Розкрито поняття: електронні освітні ресурси, віртуальні лабораторії. Показано можливості ефективного поєднання електронних освітніх ресурсів та інших технологій навчання. Встановлено, що застосування віртуального хімічного експерименту дозволяє не тільки надати студентам значної кількості знань, але і розвинути інтелектуальні, творчі здібності студентів, їх вміння самостійно здобувати нові знання, а також працювати з різними джерелами інформації. Комплексне використання реального і віртуального навчальних експериментів створює сприятливі умови для організації самостійної навчально-пізнавальної діяльності студентів.
\end{abstract}

Ключові слова: сучасні інформаційні технології навчання, електронні освітні ресурси, віртуальні лабораторії, хімічний експеримент

Постановка проблеми. Сучасне суспільство потребує креативних, професійно компетентних фахівців із високим рівнем професійного самовизначення, здатних творчо вирішувати професійні проблеми, самостійно здобувати знання та уміти застосовувати їх в різних ситуаціях. Тому перед закладами вищої освіти гостро постає завдання у підготовці вчителів, здатних до професійного саморозвитку та актуалізації власних потенційних можливостей у творчій праці.

Удосконалення якості навчання майбутніх фахівців знаходиться у прямій залежності від модернізації освіти, впровадження у практику інноваційних технологій. Модернізація системи вітчизняної освіти обумовлює необхідність пошуку нових підходів до організації навчального процесу. Один з них пов'язаний 3 інформатизацією освіти. Сучасна інформатизація системи освіти вирішує завдання ефективного використання електронних освітніх ресурсів для побудови освітнього процесу та організації взаємодії всіх суб'єктів цього процесу. Актуальним це $є$ і під час вивчення хімічних дисциплін майбутніми вчителями природничого профілю.

Одним з найбільш перспективних напрямків використання інформаційних технологій в хімічній освіті $\epsilon$ комп'ютерне моделювання хімічних явищ і процесів, вбудовування в освітній процес віртуальних лабораторних робіт. Однак, слід враховувати що впровадження інформаційних технологій в освітній процес буде виправдано тільки тоді, коли вони ефективно доповнять існуючі технології навчання або матимуть додаткові переваги в порівнянні з традиційними формами навчання.

Аналіз останніх досліджень. Використання сучасних інформаційних технологій в освітньому процесі висвітлені в роботах багатьох відомих вчених, зокрема: Н. Апатової, А. Ашерова, І. Богданової, Б. Гершунського, А. Довгялло, М. Жалдака, В. Лапінського, В. Мадзігона, Л. Панченко, Є. Полат, Ю. Рамського, Л. Романишиної та ін.

В роботах А. Аспіцької, С. Дендербера і О. Ключнікова, Г. Мальченко і О. Каретнікова, М. Тукало знаходимо обгрунтування застосуванню комп'ютерних технологій у процесі вивчення хімії.

Сьогодні велика увага приділяється розробці та використанню в навчальному процесі електронних освітніх ресурсів, в тому числі віртуальних лабораторій (Якушкина, Алексеева, 2005).

М.М. Гомуліна стверджує, що сучасний електронний освітній ресурс інтенсифікує навчальний процес і може використовуватися в процесі закріплення нових знань, відпрацювання умінь і навичок. (Гомулина, 2008, с.26).

В. Ю. Биков і В.В. Лапінський пропонують таке визначення: «Електронний освітній ресурс (ЕОР) сукупність електронних інформаційних об'єктів (документів, документованих відомостей та інструкцій, інформаційних матеріалів та ін.), інформаційно-об'єктне наповнення електронних інформаційних систем (електронних бібліотек, архівів, банків даних, інформаційно-комунікаційних мережах та ін.), призначених для інформаційного забезпечення функціонування і розвитку системи освіти (СО)» (Биков, Лапінський, 2012,c.4). 
В.В. Гура зазначає, що під електронним освітнім ресурсом можна вважати частину культурної діяльності, зафіксованої на електронному носії у вигляді програми яка служить для задоволення інформаційно-освітніх потреб суб'єктів освітнього процесу (студентів, викладачів, адміністрації) (Гура, 2007).

М. Дольме пропонує називати електронний освітній ресурс програмно-методичним навчальним комплексом, що відповідає типовій навчальній програмі і котрий забезпечує можливість студенту самостійно або за допомогою викладача освоїти навчальної курс або його розділ (Дольме, 2015, с. 98).

Згідно з (Федасюк, Гоц, Микийчук, 2016), під ЕОР розуміють навчальні, наукові, інформаційні, довідкові матеріали та засоби, розроблені в електронній формі та представлені на носіях будь-якого типу або розміщені у комп'ютерних мережах, які відтворюються за допомогою електронних цифрових технічних засобів і необхідні для ефективної організації навчально-виховного процесу в частині, що стосується його наповнення якісними навчально-методичними матеріалами.

Поняття електронних освітніх ресурсів в Наказі Міністерства освіти і науки України від 01.10.12 p. визначається як: «навчальні, наукові, інформаційні, довідкові матеріали та засоби, розроблені в електронній формі та представлені на носіях будь-якого типу або розміщені в комп'ютерних мережах, які відтворюються за допомогою електронних цифрових технічних засобів і необхідні для ефективної організації навчально-виховного процесу, в частині, що стосується його наповнення якісними навчальнометодичними матеріалами». У Наказі наводиться така класифікація видів ЕОР: електронний документ, електронне видання, електронні дидактичні демонстраційні матеріали; інформаційна система; депозитарій електронних ресурсів; комп'ютерний тест; електронний словник; електронний довідник; електронна бібліотека цифрових об'єктів; електронний навчальний посібник; електронний підручник; електронні методичні матеріали; курс дистанційного навчання; електронний лабораторний практикум.

Впровадження інформаційно-комунікативних технологій (ІКТ) в навчальний процес під час вивчення дисциплін природничого профілю (фізика, хімія та біологія) мотивується слабкою лабораторнопрактичною підтримкою навчального процесу. У зв'язку з цим широко впроваджуються віртуальні лабораторії, де з використанням засобів комп'ютерного моделювання створюється віртуальне середовище, імітуючи реальну дійсність, з якою взаємодіє експериментатор. Цей напрямок розвитку сучасних освітніх технологій досить плідно розвивається та впроваджується на всіх рівнях - від закладів середньої освіти до закладів вищої освіти. Сучасні тенденції розвитку освітньої системи припускають впровадження комп'ютерних технологій в навчальний процес, стимулюють появу віртуального навчання, віртуальних шкіл, які сприяють формуванню самостійної, творчо розвиненої особистості, яка бере участь в усіх сферах суспільного життя. Особливо гостро це питання стоїть в базової ланці освіти - середній школі, де, на думку ряду дослідників (Забара, 2014; Якушкина, Алексеева, 2005), необхідно більш широке впровадження уроків з використанням електронних навчальних матеріалів, в т.ч. й віртуальних лабораторій.

Віртуальна лабораторія (ВЛ) - це віртуальне навчальне середовище, яке дозволяє моделювати поведінку об'єктів реального світу в комп'ютерному середовищі і допомагає в оволодінні новими знаннями і вміннями. Така лабораторія може виступати апаратом досліджень різних природних явищ з можливістю побудови їх математичних і фізичних моделей (Семеніхіна, 2011, с. 342).

За визначенням В.В. Трухіна, ВЛ - це програмно-апаратний комплекс, що дозволяє проводити досліди без безпосереднього контакту з реальною установкою або при повній їі відсутності (Трухин, 2003, с. 62).

За Е.А. Козловським і М. Кравцовим, ВЛ - це віртуальна програмне середовище, в якому організовано можливість проведення досліджень моделей об'єктів, їх сукупностей і похідних, заданих з певною часткою деталізації щодо реальних об’єктів, в рамках певної галузі знань (Козловский, Кравцов, 2011, с.103].

Під віртуальною лабораторної роботою з хімії ми будемо розуміти віртуальне програмне середовище, яке дозволяє проводити віртуальний хімічний експеримент у вигляді сукупності дослідів, котрі об'єднані спільною метою вивчення речовин або хімічних процесів, при цьому студент оперує образами речовин і компонентів обладнання, що відтворюють зовнішній вигляд і функції реальних предметів.

Мета статті: проаналізувати сучасні можливості та шляхи використання у процесі вивчення хімії електронних освітніх ресурсів в сучасних закладах вищої освіти, простежити особливості використання віртуальних лабораторій на різних етапах проведення лабораторних робіт з хімії.

Виклад основного матеріалу.У закладах вищої освіти використання віртуальних лабораторій дозволить більш широко впроваджувати дистанційне навчання, що використовує сучасні інформаційнокомунікаційні технології та сприяє якісному навчанню нового покоління вчителів інтегрованих курсів 3 урахуванням індивідуальних можливостей і потреб кожного. Під час підготовки вчителів інтегрованих курсів природознавчих дисциплін спостерігається необхідність формування гнучкості мислення, професійної мобільності, універсальності фахової компетентності, які забезпечуватиме відкритість інноваційним процесам, готовності до змін, поширення кваліфікаційно-професійних компетентностей. До того ж засоби ІКТ дозволяють індивідуалізувати навчальний процес, що особливо $є$ важливим, коли студент, сам виконуючи досліди і спостереження, розв'язує самостійні індивідуальні дослідницькі завдання та проводить систематичні дослідження, що набувають системного характеру у здійсненні пізнання оточуючого світу і разом з тим стають однією з головних актуальних проблем у процесі підготовки у закладах вищої освіти високопрофесійного інтегрованого фахівця. Досить актуальним питанням $\epsilon$ реалізація принципу наочності завдяки запровадженню комп'ютерної техніки і засобів інформаційнокомунікативних технологій, що дає можливість суттєво активізувати пізнавальну діяльність студента та 
індивідуалізувати процес навчання. При цьому комп'ютерна техніка і засоби ІКТ можуть бути використані як засоби моделювання складних хімічних експериментів, експериментальної установки для дослідження хіміко-технологічних процесів, а також створення імітаційних моделей, коли компютер не лише імітує досліджуване явище, а й виконує роль інструмента для вивчення цього явища тощо (Забара, 2014). 3а цих обставин треба зауважити, що комп'ютерна техніка та засоби ІКТ не можуть замінити роботу з реальними об'єктами, хімічними реактивами, посудом та приладами. Мета віртуального хімічного експерименту полягає в тому, щоб доповнити ту інформацію, яку студенти отримують з різних першоджерел або під час занять, в ході виконання спостережень і дослідів, або у процесі формування спершу ближчих, а згодом більш віддалених взаємозв'язків і взаємозалежностей в явищах і процесах, або для розкриття на основі прийнятих моделей механізму і сутності перебігу цих процесів і явищ.

У зв'язку з цим виникла необхідність удосконалення практичних занять, саме під час вивчення хімії, в першу чергу, лабораторних практикумів. В цьому аспекті перспективною є розробка сучасної методики виконання хімічного практикуму з дисципліни «Загальна та неорганічна хімія» з урахуванням поєднання реального і віртуального хімічного експериментів, що передбачає можливість реалізації елементів комплексного підходу у процесі підготовки майбутніх вчителів природознавчих дисциплін.

Нами складена та апробована методика організації комплексних лабораторних занять під час вивчення студентами - майбутніми вчителями хімії та біології, базового фахового курсу - загальної та неорганічній хімії. Поставлено за мету комбінування традиційних форм демонстраційних експериментів та лабораторних практикумів з різними видами віртуальних робіт. Розроблено сценарій віртуальних інтерактивних лабораторних робіт з дисципліни «Загальна та неорганічна хімія» та після контактної і дистанційної апробації скоректовано та складено проект методичних розробок по віртуальному лабораторно-хімічному практикуму з даної дисципліни для студентів педагогічних університетів, що вивчають природознавчі дисципліни.

Дидактично обгрунтована послідовність роботи в інформаційно-освітньому середовищі віртуальної хімічної лабораторії складається з наступних етапів:

етап 1 - вивчення теоретичного матеріалу;

етап 2 - осмислення і закріплення теорії під час підготовки за питаннями до самоконтролю чи розв'язуванні блоку тестових завдань тощо (практична робота);

етап 3 - придбання і розвиток практичних умінь, накопичення професійного досвіду з використанням віртуальних лабораторних практикумів;

етап 4 - вирішення практичних завдань за допомогою наукомістких спеціалізованих програм i програмного забезпечення.

Оскільки під час проведення звичайної лабораторної роботи теоретичні та практичні завдання змінюють одне одного, подібний підхід збережено під час реалізації віртуальної лабораторії. Значна частка часу заняття відводиться для вирішення завдання, що ілюструє проведений хімічний експеримент. Таким чином, стандартна лабораторна робота, зазвичай $є$ ланцюжком дидактичних етапів - модулів, що складають в окремий модуль віртуального хімічного експерименту (рис.1).

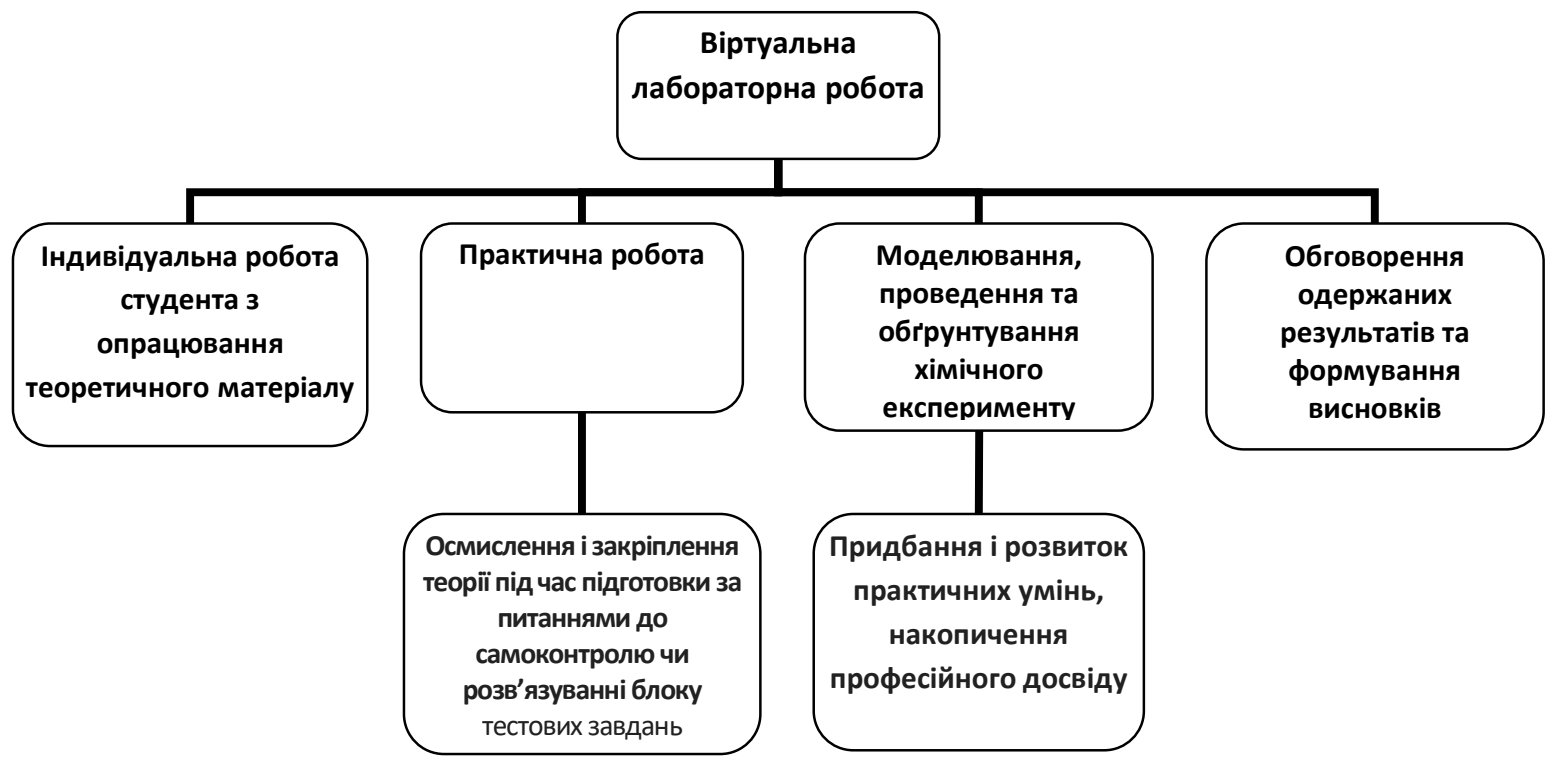

Рис.1. Дидактична структура модуля віртуальної хімічної лабораторної роботи

Так, наприклад, сценарій лабораторних робіт за темами «Класи неорганічних сполук», «Хімічний зв'язок та будова молекул» включають теоретичну частину в інтерактивній формі, що містить питання та тестові завдання для самопідготовки, осмислення методики виконання віртуального дослідження, ознайомлення з програмним забезпеченням та перевірки рівня засвоєного теоретичного матеріалу; 
експериментальну частину, що доповнена хімічними анімаційними та відео експериментами та складається з розрахункових завдань по обчисленню результатів віртуального хімічного експерименту та завдань по моделюванню вихідних та кінцевих речовин, що приймають участь в реакціях, прогнозування вірогідності їх взаємодії тощо.

У заключній частині проводиться обговорення результатів хімічного експерименту, запис розрахунків, спостережень, формулювання висновків та заповнення підготовлених таблиць, направлених на аналіз та усвідомлення ступеня досягнення мети після виконання віртуального дослідження.

Для перевірки об'єктивності з'ясування практичного стану досліджуваної проблеми під час проведення педагогічного експерименту по впровадженню комплексного лабораторного практикуму з дисципліни «Загальна та неорганічна хімія» нами було проведено бесіди та анкетування серед здобувачів вищої освіти ступенів бакалавра II - IV курсів природничо-географічного факультету ЦДПУ імені Володимира Винниченка, що навчаються за предметною спеціальністю «Середня освіта. Хімія» та «Середня освіта. Біологія та здоров'я людини». Їм були поставлені наступні запитання: Як ви вважаєте, чи вирішена у методичному плані проблема організації та проведення комплексного хімічного експерименту у закладах вищої та середньої освіти за допомогою реального та віртуального лабораторного практикуму? Чи достатньо методичної літератури, в якій розкриваються питання організації та проведення комплексного хімічного експерименту у закладах вищої та середньої освіти методом реального та віртуального хімічного експерименту?

Із результатів анкетування ми визначили, що 2,25 \% опитаних вважають - проблема методичного забезпечення, організації та проведення комплексного хімічного експерименту за допомогою реального та віртуального лабораторного практикуму у закладах вищої та середньої освіти вирішена повністю; 59,43 \% зазначили, що проблема вирішена частково; 38,32 \% відповіли, що проблема не вирішена. Це наочно демонструє діаграма (рис.2).

Таким чином, проведення лабораторного практикуму шляхом включення віртуальних лабораторних робіт під час навчання дозволяє активізувати дослідницьку діяльність майбутніх вчителів. Крім того, обов'язкове виконання віртуальних лабораторних робіт систематизує індивідуальну самостійну роботу 3 хімії, підкреслює іï роль як в загальній успішності з предмету, так і в успішному формуванні професійних компетентностей.

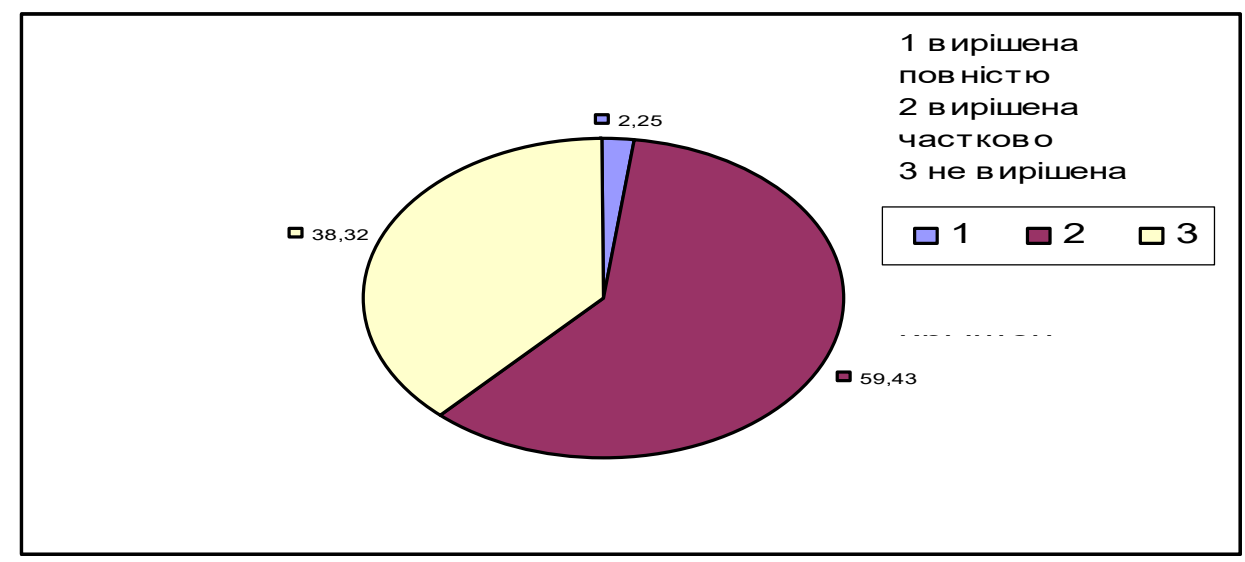

Рис. 2 Вирішення проблеми організації та проведення комплексного хімічного експерименту (\%)

Висновки. Застосування віртуального хімічного експерименту дозволяє не тільки надати студентам значної кількості знань, але і розвинути інтелектуальні, творчі здібності студентів, їх вміння самостійно здобувати нові знання, а також працювати з різними джерелами інформації. Доцільність застосування комп'ютерних технологій в процесі вивчення хімічних дисциплін не викликає сумнівів. Ефективність навчання значно підвищується, якщо використовувати їх не епізодично, а системно, протягом усього курсу (Манойлова, 2001, с. 25).

Проте очевидно, що віртуальна лабораторія має цілком певні обмеження, обумовлені припущеннями і спрощеннями, покладеними в основу математичної моделі експерименту. Безперечно, під час підготовки майбутнього вчителя природознавчих дисциплін важливе значення має виконання навчального експерименту в лабораторних умовах. Тому, саме комплексне використання реального і віртуального навчальних експериментів створює сприятливі умови для організації самостійної навчально-пізнавальної діяльності студентів за рахунок розширення меж пізнавальних можливостей студентів; збільшення обсягу навчальної інформації, доступної для самостійного оволодіння; забезпечення й отримання повної і точної інформації про явище, процес чи закономірність. 


\section{Список використаних джерел}

Наказ Міністерства освіти та науки, молоді та спорту України від 01.10.2012 № 1060 Про затвердження положення про електронні освітні ресурси [Електронний ресурс]. - Режим доступу : http://zakon5.rada.gov.ua/laws/show/z1695-12. - Назва з екрана.

Биков, В.Ю., Лапінський, В.В. (2012. )Методологічні та методичні основи створення і використовування електронних засобів навчального призначення Комп 'ютер у школі та сім ’̈, 2 (98), 3-6.

Гомулина, Н.Н. (2008) Особенности формирования электронных образовательных ресурсов для интерактивных досок. Коллекция мультимедиа-инструментов «Умник - ПО» Информационные и коммуникационные технологии в подготовке учителя физики : материалы научно-практической конференции (с. 25-27) . Коломна, 8-10 апреля 2008 г. /Коломенский гос. Ин-т .

Гура, В.В. (2007). Теоретические основы педагогического проектирования личностно-ориентированных электронных образовательных ресурсов и сред (автореф. дисс.. ... докт. пед.. наук). - Ростов на Дону.

Дольме, М. (2015). Електронні освітні ресурси як складова електронного навчально-методичного комплексу в підготовці майбутніх учителів технологій. Психолого-педагогічні проблеми сільської школи Випуск 52,.97102.

Забара, О.А. (2014). Методика проведення фізичного практикуму у педагогічному ВНЗ на основі синергетичного підходу до його організації Наукові записки. - Серія: Педагогічні науки. Кіровоград

Козловский, Е.О. , Кравцов, Г.М. (2011). Виртуальная лаборатория в структуре системы дистанционного обучения Информационные технологии в образовании. 10, 102-109.

Манойлова, С. П. (2001). Використання комп’ютера на уроках хімії. Біологія та хімія в школі. 5, $22-25$.

Семеніхіна, О.В., Шамоня, В.Г. (2011) Віртуальні лабораторії як інструмент навчальної та наукової діяльності. Педагогічні науки: теорія, історія, інноваційні технологї. Суми: Вид-во СумДПУ імені А.С. Макаренка, 1, 341-346.

Трухин, А.В. (2003) Виды виртуальных компьютерных лабораторий. Открытое и дистанционное образование. № 3-4, 58-67.

Федасюк, Д., Гоц, Н., Микийчук, М. (2016). Формування системи вимог до електронних освітніх ресурсів вищого навчального закладу з метою їх сертифікації. Вісник Національного університету „Львівська політехніка" Серія: Інформатизачія вищого навчального закладу. Львів : Видавництво Львівської політехніки, 853, 47-58.

Якушкина, А.А., Алексеева, Е. В.(2005) . Виртуальные лаборатории. Вопросы информатизации образования.

\section{References}

Nakaz Ministerstva osvity ta nauky, molodi ta sportu Ukrainy vid 01.10.2012 № 1060 Pro zatverdzhennia polozhennia pro elektronni osvitni resursy [Elektronnyi resurs]. - Rezhym dostupu : http://zakon5.rada.gov.ua/laws/show/z169512. - Nazva z ekrana.

Bykov, V.Iu., Lapinskyi, V.V. (2012) Metodolohichni ta metodychni osnovy stvorennia i vykorystovuvannia elektronnykh zasobiv navchalnoho pryznachennia. Kompiuter u shkoli ta simi, 2 (98), 3-6.

Homulyna, N.N. (2008) Osobennosty formyrovanyia эlektronnыkh obrazovatelnыkh resursov dlia ynteraktyvnыkh dosok. Kollektsyia multymedya-ynstrumentov «Umnyk - PO» Ynformatsyonnble y kommunykatsyonnble tekhnolohyy $v$ podhotovke uchytelia fyzyky : materyalbi nauchno-praktycheskoi konferentsyy (s. 25-27). Kolomna, 8-10 aprelia 2008 h. /Kolomenskyi hos. Yn-t .

Hura, V.V. (2007). Teoretycheskye osnovb pedahohycheskoho proektyrovanyia lychnostno-oryentyrovannblkh эlektronnblkh obrazovatelnblkh resursov y sred (avtoref. dyss.. ... dokt. ped.. nauk). - Rostov na Donu.

Dolme, M. (2015). Elektronni osvitni resursy yak skladova elektronnoho navchalno-metodychnoho kompleksu v pidhotovtsi maibutnikh uchyteliv tekhnolohii. Psykholoho-pedahohichni problemy silskoi shkoly Vypusk 52,.97-102.

Zabara, O.A. (2014). Metodyka provedennia fizychnoho praktykumu u pedahohichnomu VNZ na osnovi synerhetychnoho pidkhodu do yoho orhanizatsii. Naukovi zapysky. - Seriia: Pedahohichni nauky. Kirovohrad

Kozlovskyi, E.O., Kravtsov, H.M. (2011). Vyrtualnaia laboratoryia v strukture systemы dystantsyonnoho obuchenyia Ynformatsyonnble tekhnolohyy v obrazovanyy. 10, 102-109.

Manoilova, S. P. (2001)Vykorystannia kompiutera na urokakh Biolohiia ta khimiia v shkoli. 5, 22-25.

Semenikhina, O.V., Shamonia, V.H. (2011) Virtualni laboratorii yak instrument navchalnoi ta naukovoi diialnosti. Pedahohichni nauky: teoriia, istoriia, innovatsiini tekhnolohii. Sumy: Vyd-vo SumDPU imeni A.S. Makarenka, 1, 341-346.

Trukhyn, A.V. (2003) Vydы vyrtualnыkh kompiuternыkh laboratoryi. Otkrbtoe y dystantsyonnoe obrazovanye. № 3-4, 58-67.

Fedasiuk, D., Hots, N., Mykyichuk, M. (2016). Formuvannia systemy vymoh do elektronnykh osvitnikh resursiv vyshchoho navchalnoho zakladu z metoiu yikh sertyfikatsii. Visnyk Natsionalnoho universytetu „Lvivska politekhnika" Seriia: Informatyzatsiia vyshchoho navchalnoho zakladu. Lviv : Vydavnytstvo Lvivskoi politekhniky, 853, 47-58.

Yakushkyna, A.A., Alekseeva, E. V.(2005) . Vyrtualnыe laboratoryy. Voprosb ynformatyzatsyy obrazovanyia 


\title{
BOKHAN IU., FOROSTOVSKA T.
}

Volodymyr Vynnychenko Central Ukrainian State Pedagogical University, Kropivnitsky, Ukraine

\section{KORMOSH ZH.}

Lesya Ukrainka Eastern European National University, Lutsk, Ukraine

\section{APPLYING OF THE COMPLEX APPROACH TO THE CHEMICAL WORKSHOP WHILE PREPARING FUTURE TEACHERS OF NATURE STUDY DECSIPLINES}

The article deals with the preparation of teachers of integrated courses of Nature Studying discipline with the usage of modern information techniques while studying the course "General and Nonorganic Chemistry". One of the most perspective ways of usage of computer techniques in chemical education is making computer models of chemical phenomenon and processes, including virtual lab works in the process of education. Applying of informational technologies in the process of education studying the disciplines of natural approach (Physics, Chemistry and Biology) is motivated by low laboratorial and practical support of the studying process. According to this fact virtual environment is created by means of computer modeling and the experimentalist works with an imitated reality. Such notions as electronic educational resources, virtual labs are revealed. Possibilities of effective combination of electronic educational resources and other techniques of studying are indicated. The article suggests the methodology of organization of complex laboratory works for students who are future teachers of Chemistry and Biology, basic profile course of General and Nonorganic Chemistry. The article demonstrates the didactic structure of the delivery of virtual Chemistry lab for the course "General and Non-organic Chemistry". The combination of traditional forms of demonstrative experiments and lad training with different kinds of virtual works in the preparation of the students of the Natural Course is proved. The article defines that the usage of virtual chemical experiment allows not only to give the students all necessary knowledge, but it gives the opportunity to develop intellectual and creative students' skills, their ability to gain new knowledge by themselves and work with the different sources of information. The complex usage of real and virtual education experiment conducts favorable conditions for organization of independent students' studying activity by means of widening limits of cognitive abilities of students: increasing the amount of educational information which is accessible for independent studying; providing and getting complete and accurate information about any event, process or rule.

Key words: modern informational technologies of studying, electronic educational resources, virtual laboratories, chemical experiment

Стаття надійшла до редакції 09.09. 2018 р.

УДК 37.014.2(477.53)«1914-1918»

\section{ЛЕОНІД БУЛАВА}

ОЛЬГА МАЩЕНКО

АНДРІЙ ТКАЧЕНКО

Полтавський національний педагогічний університет імені В. Г. Короленка

\section{ІСТОРІЯ ПОЛТАВСЬКОГО УЧИТЕЛЬСЬКОГО ІНСТИТУТУ: ПОВЕРТАЮЧИСЬ ДО ПРОБЛЕМИ}

\begin{abstract}
Аналізуються нові й вивчені під іншим кутом зору відомі матеріали про діяльність Полтавського учительського інституту впродовж 1914-1919 років. Зокрема, увага акцентується на нещодавно виявленому фото з підписами прізвищ однокурсників А.С. Макаренка; простежуються професійна діяльність окремих випускників, біографії яких певною мірою відомі авторам.
\end{abstract}

Ключові слова: Полтавський учительський інститут, А.С. Макаренко, українська національна революція, історія педагогічної освіти

Постановка проблеми. 3 точки зору авторів, потребують уточнення: хронологічні рамки діяльності закладу; періодизація організації освітнього процесу за його змістом; статус закладу та учасників освітнього процесу; місце закладу в освітній мережі того часу міста Полтави й регіону. Потребують подальшого вивчення: біографії вчителів, як організаторів освітнього процесу в інституті; біографії слухачів інституту (з точки зору реалізації результатів навчання в інституті).

Актуальність дослідження та публікації щодо проблеми. Стаття написана в розвиток попередніх досліджень авторів та за їхньою участю (Булава, Шевчук \& Мащенко, 2014; Булава \& Мащенко, 2018; Булава 